\title{
The Levels of Cyclic AMP during Substrate-accelerated Death
}

\author{
By P. H. CAlCOTT, W. MONTAGUE AND J. R. POSTGATE \\ School of Biological Sciences, University of Sussex, Brighton, BNI $9 Q G$, Sussex
}

(Received 25 May 1972)

INTRODUCTION

Calcott \& Postgate (1972) discussed earlier work on substrate-accelerated death and reported that acceleration of death by the growth-limiting nutrient, or by a metabolite derived from it, was only observed on recovery media made up with a similar substrate. They also showed that gratuitous inducers, as well as lactose and its metabolites, accelerated the death of lactose-limited Klebsiella aerogenes and that $3^{\prime}, 5^{\prime}$-cyclic AMP protected organisms against substrate-accelerated death. The last observation linked substrate-accelerated death with catabolite repression and prompted the study of cyclic AMP levels in starved $K$. aerogenes reported here.

\section{METHODS}

Klebsiella aerogenes ( $\mathrm{NCTC} 4 \mathrm{I}$ ) ) was cultivated at $37^{\circ} \mathrm{C}$ in air in a chemostat under lactoselimitatioli as described by Calcott \& Postgate (1972). Culture samples were harvested, washed and starved in saline phosphate $(0.13 \mathrm{M}-\mathrm{NaCl}+0.02 \mathrm{M}$-sodium phosphate, $\mathrm{pH} 7 \cdot 4)$ at $37^{\circ} \mathrm{C}$ at either 20 or $100 \mu \mathrm{g}$ bacterial dry wt $/ \mathrm{ml}$. Viabilities of suitably diluted portions of the populations were determined by slide culture at $37^{\circ} \mathrm{C}$ (Postgate, Crumpton \& Hunter, 1961) on the lactose recovery medium of Calcott \& Postgate (I972).

Extraction of cyclic AMP. Portions of the starving population equivalent to approximately $2 \mathrm{mg}$ dry wt bacteria were centrifuged at $3000 \mathrm{~g}$ for $5 \mathrm{~min}$ at $3 \pm \mathrm{I}{ }^{\circ} \mathrm{C}$ and the pellets were frozen in liquid nitrogen until extracted. This step took at the most $7 \mathrm{~min}$. Each sample was treated with I $\mathrm{ml}$ of $\mathrm{I} 2 \%(\mathrm{v} / \mathrm{v})$ perchloric acid, disrupted on a Soniprobe (Dawe Instruments Ltd, London) at setting 8 ( $5 \mathrm{~A}$ ) for I min and centrifuged at $3000 \mathrm{~g}$ to remove debris. The cyclic AMP was purified from the crude extracts by a single passage through $8 \mathrm{~cm}$ columns of AG 50W-X8 200-400 mesh ion exchange resin (BioRad, Richmond, California, U.S.A.) equilibrated with $50 \mathrm{mM}-\mathrm{HCl}$. The fraction containing eluted cyclic AMP was lyophilized and stored at room temperature until assayed.

Assay of cyclic AMP. The saturation method of Brown et al. (197I) was used. Each assay tube contained $50 \mu \mathrm{l}$ (approx. $1.5 \mathrm{nCi}$ ) of tritiated cyclic AMP $(20 \mathrm{Ci} / \mathrm{mmol}$, from the Radiochemical Centre, Amersham, Buckinghamshire), $50 \mu \mathrm{l}$ of either buffer or a dilution ( $\mathrm{I}: 8$ ) of the binding protein reagent, together with $100 \mu \mathrm{l}$ of either a known amount (o to $500 \mathrm{pg}$ ) of cyclic AMP standard (Sigma Chemical Co. Ltd, London, S.W.6) or of an unknown

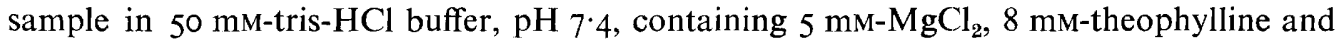
6 mM-2-mercaptoethanol.

After $\mathrm{I} \cdot 5$ to $2 \cdot 5 \mathrm{~h}$ at $4{ }^{\circ} \mathrm{C}$, $100 \mu \mathrm{l}$ of a suspension of $\mathrm{I} \mathrm{g}$ of charcoal (Norit GSX) in Io $\mathrm{ml}$ of the buffer, containing $200 \mathrm{mg}$ of bovine serum albumin (Sigma Chemical Co.), were added to each tube and mixed thoroughly. After $10 \mathrm{~min}$ at $3000 \mathrm{~g}$ and $4{ }^{\circ} \mathrm{C}, 200 \mu \mathrm{l}$ of the supernatant liquid containing the bound cyclic AMP were added to $2 \mathrm{ml}$ scintillation fluid $(70 \%$ $(\mathrm{v} / \mathrm{v})$ toluene, $30 \%(\mathrm{v} / \mathrm{v})$ Triton X-I00, $5 \%(\mathrm{w} / \mathrm{v})$ 2,5-diphenyloxazole [PPO]) and assayed 
Table I. Levels of cyclic AMP and death-rates of starved Klebsiella aerogenes

\begin{abstract}
Washed bacteria from a chemostat were starved at $37^{\circ} \mathrm{C}$ in saline phosphate buffer (see text) with the additives listed and levels of cyclic AMP were determined (see Methods). Linear death-rates were obtained from plots of viability on a lactose-based recovery medium against time of starvation. The initial content of cyclic AMP was about $2.5 \mathrm{ng} / \mathrm{mg}$ bacterial protein and the values quoted are the steady state values after more than 5 min starvation (see text).
\end{abstract}

\begin{tabular}{lcc}
\multicolumn{1}{c}{ Additive (2 mM) } & $\begin{array}{c}\text { ng cyclic AMP/ } \\
\text { mg bacterial } \\
\text { protein }\end{array}$ & $\begin{array}{c}\text { Death-rate } \\
(\% \text { dead/h) }\end{array}$ \\
None & 1.06 & 3 \\
Lactose & 0.27 & $\sim 30$ \\
IPTG & 0.23 & $\sim 30$ \\
Glycerol & 0.97 & 4 \\
Lactose + I mM- $\mathrm{MgCl}_{2}$ & 0.68 & 3 \\
Lactose + $0.5 \mathrm{~mm}^{2}$-theophylline & 0.69 & 8
\end{tabular}

for ${ }^{3} \mathrm{H}$ in a Packard-Tricarb liquid scintillation spectrometer (Model 3375). Calibration curves were plotted as radioactivity bound against amount of cyclic AMP added. The lower limit of detection in our hands was Io pg cyclic AMP/reaction tube.

Protein was estimated by the Folin phenol method of Lowry, Rosebrough, Farr \& Randall (I95I) with bovine serum albumin Fraction V (Sigma Chemical Co.) as standard.

\title{
RESULTS
}

Cyclic AMP levels in the bacteria. The steady-state level of cyclic AMP in the culture from the chemostat, running at $D=0.23 \mathrm{~h}^{-1}$, was $2.94 \mathrm{ng} / \mathrm{mg}$ bacterial protein. Harvested and washed bacteria contained about $15 \%$ less cyclic AMP $(2 \cdot 48 \mathrm{ng} / \mathrm{mg})$; the difference was accounted for as free nucleotide present in the culture fluid. On starvation at $100 \mu \mathrm{g}$ bacterial dry $\mathrm{wt} / \mathrm{ml}$, in all the environments tested, the level of the nucleotide in the bacteria decreased within 5 min to a value dependent on the composition of the starvation environment; this level then remained constant for at least $4 \mathrm{~h}$. The starvation levels of cyclic AMP (Table I) were determined under the following conditions: saline phosphate alone, saline phosphate with 2 mM-lactose (an accelerator of death), 2 mM-isopropyl- $\beta$-D-thio-galactoside (an accelerator of death), 2 mM-glycerol (a non-accelerator of death with this population), $2 \mathrm{~mm}$-lactose $+\mathrm{I} \mathrm{mm}-\mathrm{MgCl}_{2}$ (which completely protected the bacteria from lactoseaccelerated death) or $2 \mathrm{~mm}$-lactose $+0.5 \mathrm{~mm}$-theophylline (a partial protectant, see below). Cyclic AMP was detected in bacteria-free filtrates of the starvation environment: after $3 \mathrm{~h}$ starvation of $100 \mu \mathrm{g}$ equivalent bacterial dry $\mathrm{wt} / \mathrm{ml}$ populations, the saline phosphate environment contained $160 \mathrm{pg} / \mathrm{ml}$ and the saline phosphate plus lactose $360 \mathrm{pg} / \mathrm{ml}$ cyclic AMP.

From Table $\mathbf{I}$ it is evident that the pool level of cyclic AMP during starvation was important in deciding the survival chances of the population. Though starvation in saline phosphate lowered the cyclic AMP pool by approximately $60 \%$, starvation in the environment supplemented by lactose led to a much larger decrease $(\sim 90 \%)$. Starvation with glycerol, a carbon source which was utilized but did not accelerate death, decreased the pool level but only to a value comparable with that in a saline phosphate alone. Starvation with an analogue of lactose, IPTG, which accelerated death, decreased the level to that found in the organisms starved in the presence of lactose.

Protection from substrate-accelerated death by theophylline. If the pool level of cyclic AMP is important in determining the survival chances of Klebsiella aerogenes, then compounds 
which interfere with the conversion of cyclic AMP to AMP ought to affect survival. The methyl xanthine, theophylline, which inhibits animal and certain microbial phosphodiesterases (Butcher \& Sutherland, I962; Okabayashi \& Ide, I970), was not toxic, between 0.05 and $0.5 \mathrm{~mm}$, to the bacteria starved at equivalent of $20 \mu \mathrm{g}$ bacterial dry $\mathrm{wt} / \mathrm{ml}$ in saline phosphate; above I mM there was a progressive killing. Between 0.3 and $0.5 \mathrm{~mm}$-theophylline protected a population starved in the presence of its growth-limiting substrate, lactose ( $2 \mathrm{mM}$ ), nearly completely; after $3 \mathrm{~h}$, a population starved in saline phosphate $\pm 0.5 \mathrm{~mm}$ theophylline was $78 \%$ viable, one suffering from death accelerated by 2 mM-lactose was $3 \%$ viable and one incubated with 2 mm-lactose and $0.5 \mathrm{~mm}$-theophylline was $73 \%$ viable. Above 0.7 and below $0.3 \mathrm{~mm}$, theophylline did not protect the population. The content of cyclic AMP in organisms protected from lactose-accelerated death was intermediate between those from organisms which were unprotected and those starved in the absence of lactose. This is indirect evidence that theophylline influences either the formation or removal of the nucleotide in $K$. aerogenes. It does not act on the phosphodiesterase from Escherichia coli $\mathrm{KI} 2$ (Pastan \& Perlman, I970).

Effect of magnesium on the level of cyclic AMP. A fully protective concentration of magnesium chloride gave levels of cyclic AMP comparable to populations protected by theophylline, though the latter protected the population only partially (Table I).

\section{DISCUSSION}

Control of the cyclic AMP content in organisms can be brought about by three possible mechanisms: (i) the action of adenylcyclase, which converts ATP to cyclic AMP; (ii) the action of phosphodiesterase, which breaks down cyclic AMP to 5 AMP; (iii) loss of the nucleotide into the external environment (see Pastan \& Perlman, 1970). Loss is an important factor because cyclic AMP accumulated in the environment during starvation and this process was enhanced during lactose-accelerated death. The quantity detected in the starvation buffer was equivalent to about $\mathrm{I} .6 \mathrm{ng} / \mathrm{mg}$ bacterial protein which, together with that within the bacteria, accounts almost quantitatively for the cyclic AMP present in bacteria during growth. The quantity detected in the supernatant fluid of bacteria suffering from lactoseaccelerated death was $3.6 \mathrm{ng} / \mathrm{mg}$ bacterial protein which, together with $0.23 \mathrm{ng} / \mathrm{mg}$ within the bacteria, represents more than was present in the original organisms. Therefore, at least in the case of lactose-accelerated death, cyclic AMP was generated. The fact that theophylline protects is oblique evidence that there is turnover of cyclic AMP.

The cyclic AMP level is evidently important, but it is not the crucial factor responsible for lactose-accelerated death. The composition of the recovery medium is as important as the starvation environment in determining whether substrate-accelerated death occurs or not (Calcott \& Postgate, 197I, 1972). Thus, organisms starved for $4 \mathrm{~h}$ in the presence of lactose, which had lost $90 \%$ of their internal cyclic AMP and appeared nearly $100 \%$ dead when viability was determined on lactose recovery media, were over $80 \%$ viable on a glycerolbased recovery medium. Secondly, after 30 min starvation in the presence of lactose, when the pool level had dropped by $90 \%$, the majority of the organisms were still alive when tested on a lactose-based recovery medium. Some consequence of a low pool level of cyclic AMP appears to render the organism gradually susceptible to substrate-accelerated death, and they can recover from this predisposition in the absence of a traumatic substrate. 


\section{REFERENCES}

Brown, B. L., Albano, J. D. M., Ekins, R. P., Spherzi, A. M. \& Tampion, W. (i971). A simple and sensitive saturation assay method for the measurement of adenosine $35^{\prime}$-cyclic monophosphate. Biochemical Journal I21, 56I-562.

Butcher, R. W. \& Sutherland, E. W. (1962). Adenosine 3'5'-phosphate in biological materials. Journal of Biological Chemistry 237, 1244-I 250.

Calcott, P. H. \& Postgate, J. R. (I97I). Substrate-accelerated death: role of recovery media and prevention by cyclic AMP. Journal of General Microbiology 66, i.

Calcott, P. H. \& Postgate, J. R. (1972). On substrate-accelerated death in Klebsiella aerogenes. Journal of General Microbiology 70, I I 5-I 22.

Lowry, O. H., Rosebrough, N. J., Farr, A. L. \& Randall, R. J. (I95I). Protein measurement with Folin phenol reagent. Journal of Biological Chemistry 193, 265-275.

OKABAYASHI, T. \& IDE, M. (1970). Cyclic 3'5'-phosphodiesterase of Serratia marcescens. Biochimica et biophysica acta 220, I $16-123$.

Pastan, I. \& Perlman, R. (1970). Cyclic adenosine monophosphate in bacteria. Science, New York I69, 339-344.

Postgate, J. R., Crumpton, J. E. \& Hunter, J. R. (I96I). The measurement of bacterial viabilities by slide culture. Journal of General Microbiology 24, I 5-24. 